$\mathrm{Nr} 9$

WARSZAWA-KRAKóW 2006

WiESŁAWA GIERAŃCZYK

Uniwersytet Mikołaja Kopernika, Toruń

\title{
Restrukturyzacja przestrzeni przemysłowej wybranych miast woj. kujawsko-pomorskiego w okresie transformacji ustrojowej
}

Okres transformacji systemowej w polskiej gospodarce wywarł istotny wpływ na funkcjonowanie systemów osadniczych. Na początku lat 90 . XX wieku zmianie uległy zasady i mechanizmy rozwoju miast, a także ich znaczenie funkcjonalne w przestrzeni lokalnej i regionalnej, związane m.in. z wprowadzeniem rynkowych zasad gospodarowania i zmianą systemu własności.

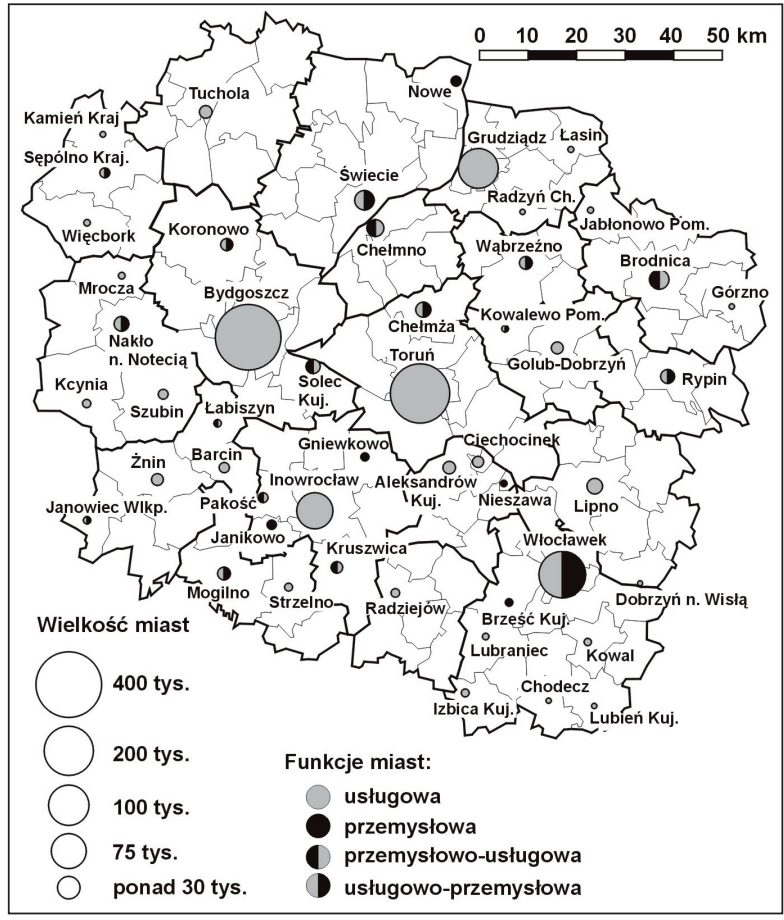

Ryc. 1. Miejska sieć osadnicza woj. kujawsko-pomorskiego 
W woj. kujawsko-pomorskim w miastach w 2003 r. zamieszkiwało 1282,7 tys. osób, co stanowiło $62,0 \%$ ogółu ludności województwa. Województwo należy więc do średnio zurbanizowanych. Do największych miast należą: Bydgoszcz (383 tys.), Toruń (205 tys.), Włocławek (123 tys.), Grudziądz (102 tys.) i Inowrocław (79 tys.). Centralne położenie dwu ośrodków stołecznych tworzy układ aglomeracyjny Bydgoszcz-Toruń, który uzupełnia równomierne rozmieszczenie tzw. miast średnich - Włocławka, Grudziądza i Inowrocławia oraz małych (ryc. 1). W okresie transformacji ustrojowej w większości miast regionu nastąpił wzrost liczby ludności (tab. 1).

Tabela 1. Ludność i pracujący w miastach woj. kujawsko-pomorskiego w 2003 r.

\begin{tabular}{|c|c|c|c|c|}
\hline Miasta & Ludność & \begin{tabular}{|c|} 
Zmiany liczby ludności \\
$1988=100$ \\
\end{tabular} & Pracujący & \begin{tabular}{|c|} 
Zmiany liczby pracujących \\
$1988=100$ \\
\end{tabular} \\
\hline Górzno & 1370 & 7,5 & 149 & $-67,9$ \\
\hline Janowiec Wielkopolski & 4261 & $-4,5$ & 657 & $-66,4$ \\
\hline Chodecz & 1943 & 8,2 & 271 & $-63,3$ \\
\hline Lubraniec & 3314 & 5,7 & 437 & $-61,2$ \\
\hline Radzyń Chełmiński & 1958 & 7,1 & 246 & $-60,6$ \\
\hline Więcbork & 5822 & 9,4 & 1065 & $-58,5$ \\
\hline Łasin & 3344 & 4,2 & 686 & $-58,1$ \\
\hline Kowalewo Pomorskie & 4124 & 0,2 & 590 & $-57,6$ \\
\hline Chełmża & 15281 & 0,2 & 2304 & $-56,8$ \\
\hline Izbica Kujawska & 2872 & 8,1 & 382 & $-56,3$ \\
\hline Grudziądz & 100205 & 0,3 & 19048 & $-54,6$ \\
\hline Pakość & 5830 & $-1,3$ & 988 & $-54,4$ \\
\hline Kowal & 3473 & 13,4 & 417 & $-54,2$ \\
\hline Kcynia & 4768 & $-1,7$ & 639 & $-53,7$ \\
\hline Strzelno & 6107 & 2,5 & 1191 & $-52,3$ \\
\hline Mrocza & 4182 & 12,5 & 528 & $-51,7$ \\
\hline Koronowo & 10785 & 9,5 & 2108 & $-51,5$ \\
\hline Mogilno & 12692 & 6,6 & 3190 & $-51,2$ \\
\hline Szubin & 9314 & 8,6 & 1804 & $-50,6$ \\
\hline Nakło n. Notecią & 19616 & $-2,0$ & 4034 & $-50,0$ \\
\hline Tuchola & 13498 & 4,2 & 3364 & $-49,7$ \\
\hline Radziejów & 5917 & $-1,7$ & 1641 & $-49,4$ \\
\hline Jabłonowo Pomorskie & 3723 & 7,7 & 752 & $-48,9$ \\
\hline Lubień Kujawski & 1350 & $-7,5$ & 246 & $-48,0$ \\
\hline Łabiszyn & 4395 & 8,1 & 597 & $-47,8$ \\
\hline Wąbrzeźno & 13883 & 4,8 & 3191 & $-47,4$ \\
\hline Żnin & 14292 & 9,2 & 3675 & $-47,3$ \\
\hline Włocławek & 121460 & 1,6 & 31322 & $-45,9$ \\
\hline Barcin & 7987 & $-2,6$ & 946 & $-45,8$ \\
\hline Brześć Kujawski & 4602 & 4,1 & 723 & $-45,8$ \\
\hline Kruszwica & 9444 & 6,1 & 2066 & $-44,8$ \\
\hline Chełmno & 20444 & $-4,0$ & 4622 & $-44,8$ \\
\hline
\end{tabular}




\begin{tabular}{|l|r|r|r|r|}
\hline Kamień Krajeński & 2285 & 14,1 & 365 & $-44,1$ \\
\hline Sępólno Krajeńskie & 9248 & 17,5 & 2239 & $-43,9$ \\
\hline Ciechocinek & 10868 & $-0,5$ & 2811 & $-43,4$ \\
\hline Aleksandrów Kujawski & 12413 & 0,7 & 2778 & $-43,3$ \\
\hline Gniewkowo & 7312 & $-1,6$ & 1674 & $-42,7$ \\
\hline Solec Kujawski & 14914 & 11,1 & 2676 & $-42,2$ \\
\hline Nieszawa & 2085 & 14,8 & 250 & $-41,7$ \\
\hline Świecie & 25956 & 3,9 & 7953 & $-41,4$ \\
\hline Golub-Dobrzyń & 13133 & 26,7 & 2410 & $-39,7$ \\
\hline Rypin & 16593 & 11,0 & 3976 & $-39,2$ \\
\hline Lipno & 14940 & 5,2 & 3849 & $-38,3$ \\
\hline Nowe & 6320 & 1,7 & 1991 & $-37,2$ \\
\hline Bydgoszcz & 366485 & $-3,0$ & 108061 & $-37,0$ \\
\hline Janikowo & 9157 & 12,6 & 2431 & $-34,5$ \\
\hline Toruń & 205114 & 2,8 & 61177 & $-34,4$ \\
\hline Dobrzyń & 2338 & 2,3 & 327 & $-32,4$ \\
\hline Brodnica & 27089 & 6,6 & 8452 & $-25,2$ \\
\hline Inowrocław & 78211 & 4,2 & 18122 & $-21,4$ \\
\hline
\end{tabular}

Źródło: obliczenia własne na podstawie www.stat.gov.pl

Miasta stanowią podstawowe środowisko działalności gospodarczej w regionie. W $2003 \mathrm{r}$. na ich obszarze zarejestrowanych było $62,9 \%$ podmiotów gospodarczych, w których zatrudniono 70,2\% ogółu pracujących w województwie kujawsko-pomorskim. Rozmieszczenie działalności gospodarczej i jej oddziaływanie na inne sfery życia społeczno-gospodarczego kształtuje strukturę funkcjonalno-przestrzenną miast i regionu. W związku z tym, iż w pięciu największych miastach Bydgoszczy, Toruniu, Włocławku, Grudziądzu, Inowrocławiu skoncentrowana jest ponad połowa potencjału gospodarczego województwa i niemal 3/4 potencjału wszystkich miast, można stwierdzić, iż wyznaczają one kierunki rozwoju całego regionu.

Przez wiele lat wyznacznikiem rozwoju gospodarczego miast był przemysł. W skali całego województwa dostrzec można stopniowy spadek znaczenia województwa kujawsko-pomorskiego w produkcji sprzedanej przemysłu Polski z 5,8\% w 1995 r. do 4,7\% w 2003, przy czym w strukturze produkcji sprzedanej wzrosła rola wyrobów tradycyjnych. Województwo zajmowało w 2002 r. 1 miejsce w kraju w zakresie produkcji soli (78,7\%), włókien syntetycznych $(58,55 \%)$, tłuszczów roślinnych $(21,6 \%)$ i cukru $(17,2 \%)$. Zaobserwowano także spadek udziału pracujących w przemyśle z 45\% w 1996 r. do 39\% w 2003 r. (ryc. 2) oraz spadek bezwzględnej liczby pracujących w przemyśle w latach 1996-2003 o 1/3 (z 253,6 tys. w 1996 do 181,5 tys. w 2003). Tendencja zachodzących zmian w strukturze pracujących wskazuje na kształtujący się proces serwicyzacji (usługowienia) gospodarki, a może raczej dezindustrializacji względnej. W tym celu na podstawie dostępnych danych dokonano analizy struktury funkcjonalnej na podstawie założeń klasyfikacji według M. Jerczyńskiego (1973). $\mathrm{Z}$ informacji zawartych w tab. 2 wynika, iż na badanym obszarze rola przemysłu w strukturze funkcjonalnej utrwaliła się tylko w pięciu niewielkich miastach (do 10 tys.), gdzie pracujący w przemyśle stanowią ponad 60\% ogółu pracujących (Brześć Kujawski, Gniewkowo, Janikowo, Nieszawa i Nowe). Wiązało się to z utrzymaniem produkcji w istniejących za- 
kładach przemysłowych bazujących na lokalnych zasobach surowcowych. W Janikowie podstawę działalności gospodarczej stanowiły Janikowskie Zakłady Sodowe „Janikosoda” SA będące wiodącym producentem sody kalcynowanej lekkiej i ciężkiej oraz największym w kraju producentem soli warzonej przemysłowej oraz spożywczej, a także bazująca na przetwórstwie miejscowych płodów rolnych Cukrownia Janikowo. W Gniewkowie największe zakłady przemysłowe to: „Bonduelle” zajmujący się przetwórstwem owocowo-warzywnym, „Interlight” Production and Selling produkujące świece, Bydgoskie Fabryki Mebli S.A. Zakład w Gniewkowie oraz Zakłady Mechaniczne Przemysłu Ceramiki Budowlanej „Cerama” Spółka z o.o. Przemysł miast Nieszawy, Brześcia Kujawskiego i Nowego koncentrował się na przetwórstwie płodów rolnych, przy czym w Brześciu Kujawskim rozwinięty jest także przemysł elektromaszynowy (Fabryka Maszyn Rolniczych produkująca elektroniczne opryskiwacze, Zakład Obróbki Metali „Unimet”). Utrwalenie się funkcji przemysłowej w tych miastach miało jednak charakter relatywny. Wynikało bowiem nie z rozwoju przemysłu - w żadnym z podanych miast zatrudnienie w przemyśle w latach 1996-2003 nie wzrosło, ale z większego spadku pracujących w usługach. Potencjał miast woj. kujawskopomorskiego, które dziś określić można by mianem przemysłowych - wyrażony liczbą pracujących - stanowi niespełna 2,5\% ogółu pracujących w przemyśle w miastach omawianego obszaru. Stąd stwierdzić można, iż kierunek rozwoju przemysłu w regionie wyznacza pięć największych miast (Bydgoszcz, Toruń, Włocławek, Grudziądz, Inowrocław), w których koncentruje się ponad połowa pracujących i podmiotów przemysłowych całego województwa i 3/4 potencjału przemysłowego zlokalizowanego w miastach (ryc. 3).

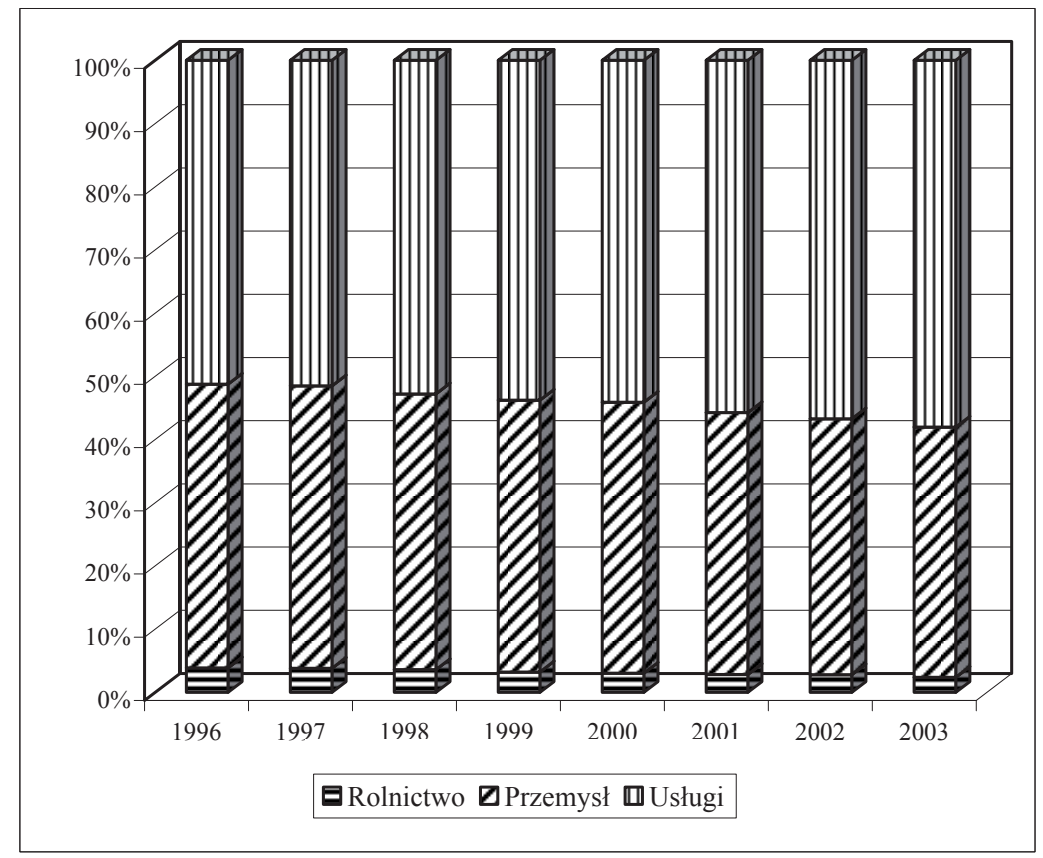

Ryc. 2. Struktura pracujących w woj. kujawsko-pomorskim w latach 1996-2003 

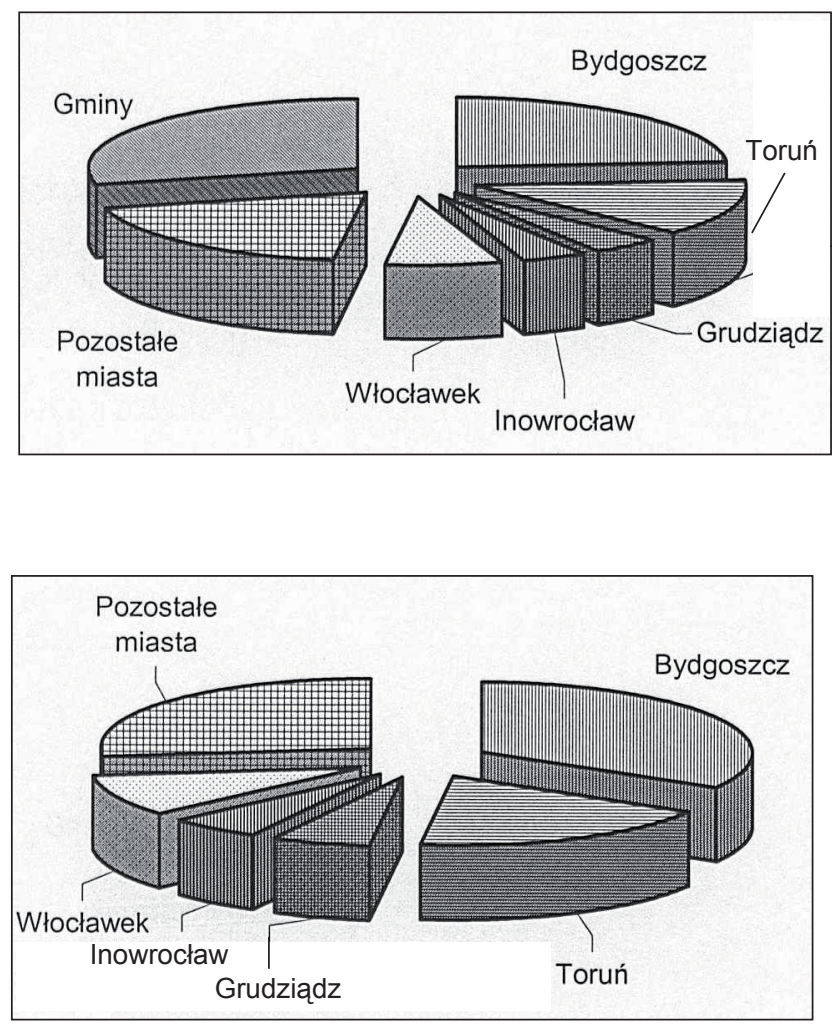

Ryc. 3. Pracujący w przemyśle w woj. kujawsko-pomorskim w 2003 r.

Największe miasta województwa mają też długą tradycję w rozwoju przemysłu - począwszy od czasów średniowiecznych, kiedy to ważnym czynnikiem lokalizacji były szlaki wodne, nad którymi te miasta się znajdują (zespoły stoczniowo-portowe), po okres industrializacji socjalistycznej, kiedy to w miastach tych powstały wielkie zakłady przemysłu chemicznego, celulozowo-papierniczego, drzewnego itp. (np. w Bydgoszczy Zakłady Chemiczne „Zachem”, w Toruniu Zakłady Włókien Chemicznych „Elana”, we Włocławku Zakłady Azotowe, w Grudziądzu Grudziądzkie Zakłady Przemysłu Gumowego „Stomil” SA, rozbudowane na bazie powstałych w 1923 r. zakładów PePeGe).

Przeprowadzona na podstawie dostępnych danych analiza struktury funkcjonalnej za 2003 r. wskazuje, iż obecnie miasta te stanowią centra usługowe, które zapewniają prawidłową obsługę mieszkańców regionu. Jako całkowicie wykształcone centra usługowe można uznać największe ośrodki - Bydgoszcz i Toruń, które są w pełni wyposażone w usługi wyższego rzędu (III sektor). Wymienić tu należy przede wszystkim usługi w zakresie szkolnictwa wyższego (pod względem liczby studentów łączny potencjał Bydgoszczy i Torunia jest większy niż np. Gdańska, Katowic i Szczecina), wyspecjalizowaną służbę zdrowia (część placówek medycznych - zwłaszcza związanych z leczeniem nowotworów, ginekologią i okulistyką należy do wyspecjalizowanych i wiodących w skali kraju), instytucje kultury i obsługę finansową. 
Tabela 2. Typy funkcjonalne miast regionu kujawsko-pomorskiego w latach 1973-1998 (wg klasyfikacji M. Jerczyńskiego)

\begin{tabular}{|c|c|c|c|}
\hline \multirow{2}{*}{ Wyszczególnienie } & \multicolumn{3}{|c|}{ Typ funkcjonalny } \\
\hline & 1973 & 1988 & 2003 \\
\hline Aleksandrów Kujawski & UP & $\mathrm{U}$ & $\mathrm{U}$ \\
\hline Barcin & $\mathrm{P}$ & UP & $\mathrm{U}$ \\
\hline Brodnica & UP & UP & $\mathrm{PU}$ \\
\hline Brześć Kujawski & $\mathrm{PU}$ & UP & $\mathrm{P}$ \\
\hline Bydgoszcz & $\mathrm{P}$ & $\mathrm{PU}$ & $\mathrm{U}$ \\
\hline Chełmno & $\mathrm{PU}$ & $\mathrm{PU}$ & $\mathrm{PU}$ \\
\hline Chełmża & $\mathrm{P}$ & $\mathrm{PU}$ & UP \\
\hline Chodecz & UP & $\mathrm{U}$ & $\mathrm{U}$ \\
\hline Ciechocinek & $\mathrm{U}$ & $\mathrm{U}$ & $\mathrm{U}$ \\
\hline Dobrzyń & RU & UR & $\mathrm{U}$ \\
\hline Gniewkowo & $\mathrm{PU}$ & $\mathrm{PU}$ & $\mathrm{P}$ \\
\hline Golub-Dobrzyń & UP & UP & $\mathrm{U}$ \\
\hline Górzno & $\mathrm{R}$ & UP & $\mathrm{U}$ \\
\hline Grudziądz & $\mathrm{P}$ & $\mathrm{PU}$ & $\mathrm{U}$ \\
\hline Inowrocław & UP & $\mathrm{P}$ & $\mathrm{U}$ \\
\hline Izbica Kujawska & PR & $\mathrm{U}$ & $\mathrm{U}$ \\
\hline Jabłonowo Pomorskie & UR & $\bar{U}$ & $\mathrm{U}$ \\
\hline Janikowo & $\mathrm{P}$ & $\mathrm{P}$ & $P$ \\
\hline Janowiec Wielkopolski & PU & $\mathrm{PU}$ & UP \\
\hline Kamień Krajeński & $\mathrm{U}$ & $\mathrm{U}$ & $\mathrm{U}$ \\
\hline Kcynia & UP & $\mathrm{U}$ & $\mathrm{U}$ \\
\hline Koronowo & $\mathrm{PU}$ & $\mathrm{PU}$ & $\mathrm{U}$ \\
\hline Kowal & $\mathrm{X}$ & UP & $\mathrm{U}$ \\
\hline Kowalewo Pomorskie & $\mathrm{X}$ & $\mathrm{U}$ & UP \\
\hline Kruszwica & $\mathrm{P}$ & $\mathrm{P}$ & $\mathrm{PU}$ \\
\hline Lipno & UP & $\mathrm{U}$ & $\mathrm{U}$ \\
\hline Lubień Kujawski & $\mathrm{U}$ & $\mathrm{U}$ & $\mathrm{U}$ \\
\hline Lubraniec & UP & $\mathrm{U}$ & $\mathrm{U}$ \\
\hline Łabiszyn & $\mathrm{PU}$ & UP & $\mathrm{PU}$ \\
\hline 七asin & UP & UP & $\mathrm{U}$ \\
\hline Mogilno & UP & $\mathrm{U}$ & UP \\
\hline Mrocza & UP & $\mathrm{U}$ & $\mathrm{U}$ \\
\hline Nakło n. Notecią & $\mathrm{PU}$ & $\mathrm{PU}$ & $\mathrm{U}$ \\
\hline Nieszawa & $\mathrm{X}$ & $\mathrm{X}$ & $\mathrm{P}$ \\
\hline Nowe & $\mathrm{P}$ & $\mathrm{P}$ & $\mathrm{P}$ \\
\hline Pakość & $\mathrm{P}$ & $\mathrm{P}$ & $\mathrm{PU}$ \\
\hline Radziejów & $\mathrm{U}$ & $\mathrm{U}$ & $\mathrm{U}$ \\
\hline Radzyń Chełmiński & $\mathrm{U}$ & $\mathrm{U}$ & $\mathrm{U}$ \\
\hline Rypin & UP & UP & UP \\
\hline Sępólno Krajeńskie & UP & $\mathrm{U}$ & UP \\
\hline
\end{tabular}




\begin{tabular}{|l|c|c|c|}
\hline Solec Kujawski & P & P & PU \\
\hline Strzelno & UR & U & U \\
\hline Szubin & U & U & U \\
\hline Świecie & PU & PU & UP \\
\hline Toruń & PU & UP & U \\
\hline Tuchola & UP & U & U \\
\hline Wąbrzeźno & UP & UP & UP \\
\hline Więcbork & PU & U & U \\
\hline Włocławek & P & PU & UP \\
\hline Żnin & UP & UP & U \\
\hline
\end{tabular}

Jednakże zwłaszcza powojenna industrializacja spowodowała, iż w przestrzeni miast regionu (podobnie jak w większości miast Polski) zarezerwowano znaczne obszary na rozwój funkcji przemysłowej. Silna presja na rozwój przemysłu, brak mechanizmów konkurencji i nieuwzględnianie renty gruntowej decydowały o tym, iż proces industrializacji realizowano głównie poprzez:

- rozbudowę już istniejących zakładów, często zlokalizowanych w sąsiedztwie dzielnic mieszkaniowych. W Toruniu np. rozbudowano Jakubskie Przedmieście - Fabryka Cukiernicza „Kopernik”, „Apator”, Toruńskie Zakłady Materiałów Opatrunkowych, Zakłady Przemysłu Ziemniaczanego (obecnie fabryka płatków kukurydzianych „Nestle”), fabryka zegarów i wodomierzy „Metron”, Chłodnia „Agrochłód”. W Bydgoszczy w latach 60 . w dzielnicach śródmiejskich zlokalizowanych było $70 \%$ wszystkich zakładów przemysłowych, m.in. Przedsiębiorstwo Cukiernicze „Jutrzenka” S.A., Pomorskie Zakłady Przemysłu Skórzanego „Kobra”, Zakłady Urządzeń Okrętowych „Famor”. W Inowrocławiu w latach 60. oddano do eksploatacji drugi szyb zlokalizowanej w centralnej części miasta kopalni soli „Solno”,

- koncentrowanie działalności przemysłowej wzdłuż wylotowych arterii miasta i tworzenie monofunkcyjnych stref użytkowania terenu. W Toruniu monofunkcyjność w zakresie działalności przemysłowej cechuje zachodnią oraz północno-wschodnią część miasta. W Bydgoszczy pod kompleksową zabudowę przemysłową przeznaczono tereny Bydgoszcz Wschód, Zimne Wody, Osową Górę, Glinki. W Inowrocławiu dominacja przemysłu w przestrzeni występuje w południowej części miasta związanej z Inowrocławskimi Zakładami Chemicznymi „Soda Mątwy” S.A. oraz w północnej części, gdzie zlokalizowana jest Huta Szkła Gospodarczego „Irena” SA i Fabryka Maszyn Rolniczych „Inofama”.

W warunkach gospodarki rynkowej tradycyjny profil produkcji przemysłowej i znaczny stopień dekapitalizacji majątku nie sprzyjały efektywności działalności, stąd większość dużych zakładów przemysłowych w regionie odnotowała regres i stanęła przed koniecznością głębokich przeobrażeń bądź likwidacji. W związku z tym, iż okres industrializacji socjalistycznej cechowała nadmierna rozrzutność w gospodarce gruntami pozostawianymi do dyspozycji zakładów przemysłowych, działania naprawcze wiązały się często z rezygnacją zakładów z części lub całości użytkowanych terenów i obiektów pozostających w ich dyspozycji. W ten sposób zostały uwolnione tereny dość łatwo dostępne, często o znacznych walorach położenia: dogodnie skomunikowanych i sąsiadujących ze śródmieściem. Pojawiła się zatem szansa restrukturyzacji przestrzeni miast, która polega na wprowadzaniu do zdegradowanego obszaru miasta innych funkcji niż poprzednio występujące. Jednak w obec- 
nych warunkach, kiedy większość miast, boryka się z kłopotami finansowymi, kiedy brak jest odpowiednich regulacji prawnych o rewitalizacji i przebudowie polskich miast, należy się zastanowić, czy uwolnione tereny poprzemysłowe nie przekształcą się $\mathrm{w}$ nową istotną barierę rozwoju. Może nią być spekulacyjne zawłaszczanie najbardziej wartościowych terenów i przypadkowość w lokowaniu nowych funkcji. Wysokie koszty użytkowania terenów w centralnych częściach miasta powodują, że ich wynajęciem bądź wykupem zainteresowane są firmy wysoko rentownych branż, do których niewątpliwie należą instytucje usługowohandlowe. W Bydgoszczy duże zainteresowanie obiektami poprzemysłowymi wykazywali inwestorzy lokujący kapitał w sklepy wielkopowierzchniowe, m.in. w obiektach Zakładów Rowerowych „Romet” po nieudanej prywatyzacji ma być wybudowany hipermarket meblowy sieci IKEA, grunty Zakładów Mięsnych Byd-meat na Fordonie wykupiła i wybudowała tam swój hipermarket firma Auchan, a na obiektach tych zakładów w centrum ma powstać Focus Park. Sytuacja taka wskazuje, iż na obszary poprzemysłowe wprowadzane są funkcje należące głównie do sektora trzeciego i czwartego, których funkcjonowanie wiąże się z istotnym przekształcaniem istniejących form przestrzennych.

Zaobserwowane w okresie transformacji zmiany w przestrzeni Bydgoszczy i innych miast woj. kujawsko-pomorskiego wydają się mieć jednak charakter spontaniczny. W dużej mierze sprzyja temu skomplikowany przebieg procesów prywatyzacyjnych oraz niski stopień świadomości władz samorządowych, które często nie uwzględniają znaczenia miejscowego planu zagospodarowania przestrzennego. Po wejściu w życie w połowie 2005 roku ustawy o planowaniu i zagospodarowaniu przestrzennym większość planów miejscowych przestała obowiązywać. Aktualne plany pokrywają w Bydgoszczy, Toruniu i Inowrocławiu ok. 20\% powierzchni miasta. Stąd nieodosobnione są przypadki dostosowywania planów miejscowych do potrzeb inwestora. Proces świadomego kształtowania atrakcyjności inwestycyjnej terenów miejskich utrudnia ponadto nieuwzględnianie w planach miejscowych ustaleń konserwatorów zabytków. Powstające między inwestorami a służbami konserwatorskimi konflikty powodują, że projekty inwestycyjne są wstrzymywane, a niektórzy inwestorzy zainteresowani historycznym otoczeniem wybierają dla swych działań obszary oddalone w innych częściach miasta, ale niezagrożone tego typu konfliktami.

$Z$ restrukturyzacją przestrzeni miast wiąże się zjawisko eksurbanizacji* i związanego z tym zjawiskiem procesu regulacji lokalizacji przemysłu. Eksurbanizacja dokonuje się poprzez usuwanie przemysłu z terenu miasta lub jego części, a z centrów miast w szczególności i przenoszenia go w dalsze części miasta lub na obszary podmiejskie. Przyczyn eksurbanizacji (dyslokacji przemysłu) z miast lub ich części jest wiele. Wydaje się, iż najważniejsze związane są z efektywnym wykorzystaniem przestrzeni, polegającym na realizacji dużych projektów urbanistycznych na terenach centralnych związanych z renowacją, budową arterii czy lokalizacją innych funkcji, np. funkcji handlowo-usługowej. Przykłady takich działań dostrzec można w przestrzeni Bydgoszczy. Ok. pięć lat temu dokonano eksurbanizacji Bydgoskich Zakładów Meblowych z dzielnicy Kapuściska, znajdującej się w centralnej części miasta, do oddalonej o ok. 6-11 km od centrum jednostki Łęgnowo I. W miejscu przeniesionej Bydgoskiej Fabryki Mebli S.A. zlokalizowano pobudowany od podstaw hipermarket TESCO. Swoją drukarnię postanowiły też wyprowadzić z centrum Zakłady Graficzne w Bydgoszczy - w zwolnionych budynkach powstać ma kolejne centrum handlowo-usłu-

* Eksurbanizacja, często nazywana także urban spraw to proces rozlewania się miast w większe obszary mniej intensywnej urbanizacji z równoczesnym definitywnym przemieszczeniem się aktywności ekonomicznej z centrum miasta na jego peryferie [Fularz 2004]. 
gowe. Eksurbanizacja przemysłu wiąże się także z dążeniem do podnoszenia jakości życia mieszkańców i eliminacji uciążliwości związanych z działalnością przemysłową. Przykłady tego typu działań można wskazać w Inowrocławiu, gdzie w celu ochrony strefy uzdrowiskowej przed działalnością przemysłu dąży się do dyslokacji zakładów przemysłowych z północnej części miasta, w której zlokalizowane są zakłady posiadające strefę oddziaływania wykraczającą poza teren zakładu, np. Huta Szkła Gospodarczego „Irena” i Inowrocławska Fabryka Sprzętu Rolniczego „Inofama” oraz w zachodniej części miasta Inowrocławskiej Spółdzielni Mleczarskiej i zakładu odzieżowego „Modus”, które sąsiadują z urodzajnymi glebami, do dzielnicy przemysłowej Południe II. Urealnienie tych zamierzeń uniemożliwia jednak brak odpowiedniej infrastruktury.

Pomimo, iż wzmożona działalność inwestycyjna, zwłaszcza w ostatnich dwóch latach, przyczynia się do kurczenia zasobów wolnej przestrzeni w miastach omawianego regionu, nieodosobnionym zjawiskiem są odłogi przemysłowe, rozumiane jako opuszczone, nieczynne i nieużytkowane tereny poprzemysłowe. Odłogi przemysłowe tworzą się poprzez porzucenie dotychczas zajmowanych terenów i budynków przemysłowych, które często pozostają niezagospodarowane. Odłogi powstają z reguły wtedy, gdy przedsiębiorstwo ulega likwidacji, pozostają nieuregulowane stosunki własnościowe i mienie niechciane. Odłogi najpowszechniej występują w regionach recesyjnych, gdzie nie ma popytu na tereny [Jałowiecki 1993]. Pomimo, iż region kujawsko-pomorski do regionów recesyjnych nie należy, niezagospodarowanych obiektów jest tu ok. 4,5 tysiąca, w tym znaczną część stanowią obiekty poprzemysłowe. Spektakularnym przykładem odłogów przemysłowych mogą być obiekty byłych Toruńskich Zakładów Przemysłu Nieorganicznego „Polchem”, ruiny Zakładów Mięsnych „Tormięs” w Toruniu, obiekty fabryki porcelany we Włocławku. Często obiekty poprzemysłowe posiadają potężne kubatury i trudno je zagospodarować. W związku z tym tereny te powinny być poddane działaniom rewitalizacyjnym. Proces ten powinien polegać na zidentyfikowaniu, zaplanowaniu i wprowadzeniu w życie nowego, efektywnego sposobu ich wykorzystania, czyli powtórnego zagospodarowania przestrzenno-funkcjonalnego [Kaczmarek 2004].

Oddzielny aspekt restrukturyzacji przestrzeni przemysłowej stanowi turystyka industrialna, która w Polsce jest zjawiskiem stosunkowo nowym. Polega ona na wykorzystaniu zabytków techniki i przemysłu dla stworzenia atrakcyjnej oferty turystycznej lub wzbogacenia już istniejącej. W woj. kujawsko-pomorskim zasoby dziedzictwa przemysłowego obejmują 1914 obiektów, z tego 75 zapisanych jest w rejestrze zabytków [Turystyka 2004]. Największą grupę stanowią obiekty związane z przemysłem rolno-spożywczym (mleczarnie, olejarnie, kaszarnie), przetwórczym (młyny - np. młyn przy zamku krzyżackim w Toruniu, brawary, gorzelnie, spichlerze, wiatraki), przemysłem odlewniczym (odlewnia żelaza i stali w Toruniu) czy maszynowym (fabryka maszyn we Włocławku). Część tych zabytkowych obiektów została zagospodarowana, np. szkielet zbiornika gazowni miejskiej w Toruniu posłużył do stworzenia planetarium, część wykorzystywana jest do bieżących potrzeb, np. dawne hale fabryki Born u. Schutze w Toruniu czy fabryki fajansu we Włocławku służą jako obiekty handlowe, tylko niektóre przygotowywane są do udostępnienia dla zwiedzających, jak np. XIX-wieczny zespół wodociągów w Toruniu.

Podsumowując, można zauważyć, iż przekształcenia struktur przestrzennych w miastach woj. kujawsko-pomorskiego dokonują się powoli. Główną barierą działań restrukturyzacyjnych przestrzeni miast (w tym rewitalizacji) jest niedobór kapitału. Obecnie na świecie i w Polsce miasta konkurują o względy inwestorów, dlatego coraz ważniejsze staje się po- 
zytywne wyróżnianie lokalnych atutów. Uogólniając, można stwierdzić, iż dynamika i charakter przekształceń $\mathrm{w}$ strukturze funkcjonalnej i przestrzeni miast zależą przede wszystkim od jakości środowiska biznesu (klimatu inwestycyjnego) i otwartości władz na inwestycje. W woj. kujawsko-pomorskim pod względem przyciągania inwestycji wyróżnia się Bydgoszcz - ósme co do wielkości miasto w Polsce. Według ratingu firmy Fitch przeprowadzonego w 2004 r. Bydgoszcz otrzymała ocenę „BBB”, co odpowiada dobrej jakości kredytowej. Dla inwestorów jest to informacja o wypłacalności i wiarygodności kredytowej miasta. Nadana ocena ratingowa jest odzwierciedleniem wyników zarządzania budżetem, elastyczności finansowej, lokalnej sytuacji gospodarczej i perspektyw jej rozwoju. Ocena wiarygodności kredytowej jest szczególnie ważna podczas rozmów z inwestorami.

Rozwój gospodarki rynkowej przywrócił w miastach znaczenie renty gruntowej jako głównego organizatora przestrzeni miejskiej. Cena ziemi wraca do roli pierwszoplanowego czynnika kształtowania struktury przestrzennej miast. Wysokie koszty użytkowania centralnych dzielnic powoduja, iż głównym czynnikiem przestrzeniotwórczym w miastach stają się usługi, które przyczyniają się do tworzenia nowych miejsc pracy oraz absorbują coraz więcej przestrzeni. Koncentrują się zwłaszcza w centralnych dzielnicach miast, natomiast w peryferyjnych dzielnicach poprzemysłowych wykształcają się nowe polifunkcyjne obszary gospodarcze miast, wskutek wydzierżawiania, bądź wyzbywania się niewykorzystanych obiektów i terenów przemysłowych, np. w zachodniej części Torunia do wykupionych od Toruńskiej Przędzalni Czesankowej „Merinotex” obiektów relokowano Instytut Archeologii UMK, wydzierżawiono biurowce dla firm usługowych, w północno-wschodniej części Torunia na tereny przemysłowo-składowe sukcesywnie wprowadzane są usługi. Zauważa się, iż lokalizacja dużych inwestycji eliminuje $\mathrm{z}$ danego terenu drobnych inwestorów. W Toruniu silna specjalizacja na terenach przemysłowo-składowych wykazuje ujemną zależność z intensywnością rozwoju drobnej przedsiębiorczości przemysłowej.

$\mathrm{Z}$ analizy struktury funkcjonalnej w miastach woj. kujawsko-pomorskiego wynika, iż przemysł jest ustępującym sektorem gospodarki. Nie należy jednak traktować przemysłu jako dziedziny schyłkowej, lecz skoncentrować działania legislacyjne i inwestycyjne na jego restrukturyzacji jakościowej. Chcąc konkurować na rynku lokalnym, krajowym i europejskim, przemysł musi poddać się transformacji strukturalnej od przemysłów prostych opartych na surowcach do przemysłów konkurencyjnych - wysokiej techniki. W omawianym regionie przejawem otwartości na działania proinnowacyjne jest utworzenie Bydgoskiego Parku Przemysłowo-Technologicznego w Bydgoszczy oraz Centrum Transferu Technologii w Toruniu. Jednostki te mają być platformą współpracy między nauką a przemysłem, sprowadzić do regionu nowoczesne know-how, dać nowe miejsca pracy, a w konsekwencji podnieść pozycję miast i regionu na arenie gospodarczej.

\section{Literatura}

Fularz A. 2004, Hipermarket a teoria ekonomiki transportu, http://www.hipermarket.most.org.pl/hipermark.pdf

Gospodarka przestrzenna miast polskich w okresie transformacji, 1998, Biuletyn KPZK PAN z. 182, Warszawa

Jałowiecki B. 1993, Polityka restrukturyzacji regionów - doświadczenia europejskie, Uniwersytet Warszawski, Warszawa

Kaczmarek S. 2004, Rewitalizacja terenów poprzemysłowych, Uniwersytet Łódzki, Łódź 
Przemiany struktury przestrzennej miast w sferze funkcjonalnej i społecznej, 2004, red. J. Słodczyk, Uniwersytet Opolski, Opole

Turystyka w obiektach poprzemystowych, 2004, Polska Organizacja Turystyczna, Warszawa

Wspótczesne przemiany struktur przestrzennych dużych miast. IX Konwersatorium Wiedzy o Mieście, 1997, Łódź

\section{Restructuring of industry space in selected cities of the Kujawsko-Pomorskie province during the period of political system transformation}

The period of system transformation in Polish economy had a great influence on the function of settlement systems. At the beginning of 1990s, the rules and mechanisms of cities development were changing, and their functional meaning in local and regional space was connected with introducing new market rules and changing the ownership system.

Functional structure analysis in cities proves that industry is giving way. However, industry should not be treated as a decadent branch, and all legislative and investment actions ought to be concentrated on quality restructuring. Industry can compete on the local, national and European market only when it goes through structural transformation, from a simple industry based on raw materials to competitive industries of high technology. In the region, the openness to actions of innovation is manifested in the creation of the Bydgoszcz Industrial-Technical Park in Bydgoszcz and the Centre of Technology Transfer in Toruń.

These units are to be the platform of cooperation between science and industry, to introduce the modern know-how to the region, to create new workplaces, and finally to upper the cities and region's position on the industrial arena. 